Received: 31.08.2020

Accepted: 24.09 .2020

Published Online: 05.10.2020

DOI: $10.18613 /$ deudfd.803354

Research Article
Dokuz Eylül University

Maritime Faculty Journal

ULK 2019 - UDTS 2020 Special Issue

pp:1-14

ISSN:1309-4246

E-ISSN: 2458-9942

\title{
CLUSTERING TURKISH CONTAINER PORTS BASED ON PHYSICAL ATTRIBUTES AND EFFICIENCY SCORES
}

\author{
Bayram Bilge SAĞLAM ${ }^{1}$ \\ Abdullah AÇIK ${ }^{2}$
}

\begin{abstract}
Due to the significant impact of port performance on overall performance of global supply chains, enhancing the efficiency of terminal operations is an important task for ports to achieve a competitive edge. By acknowledging the role that efficiency plays in port competition, there are many research in the literature revealing the relative efficiencies of ports that are under investigation and providing managerial implications for the ones that are relatively inefficient. However, in many cases, the results obtained from the efficiency analysis can be misleading on its own as the ports may have different natures in terms of their size, cargo flow potentials or the environment that they are embedded in. Therefore, focusing on Turkish container ports, our study aims to classify the ports by taking both their physical attributes and efficiency scores into consideration. In order to determine the efficiency scores our study applies data envelopment analysis and the classification of the terminals is carried out by the application of cluster analysis. Results of the clustering lead to better assessment of benchmarking options for the ports and provide a general overview of the characteristics of Turkish container port industry.

Keywords: container terminals, efficiency, data envelopment analysis, cluster analysis, benchmark.
\end{abstract}

\footnotetext{
1 Res. Asst. Dr., Dokuz Eylül University, Maritime Faculty, İzmir, bayram.saglam@deu.edu.tr, orcid.org/0000-0003-4977-1634

2 Res. Asst. Dr., Dokuz Eylül University, Maritime Faculty, İzmir, abdullah.acik@deu.edu.tr, orcid.org/0000-0003-4542-9831
}

ULK 2019- UDTS 20201 


\title{
TÜRK KONTEYNER LİMANLARININ FİZİKSEL ÖZELLİKLERİ VE ETKİNLİK SKORLARINA GÖRE KÜMELENMESİ
}

\begin{abstract}
$\ddot{O Z Z E T}$
Liman performansının küresel tedarik zincirlerinin genel performansı üzerindeki önemli etkisi nedeniyle, terminal operasyonlarının verimliliğini artırmak, limanların rekabet avantajı elde etmeleri için önemli bir gerekliliktir. Verimliliğin liman rekabetinde oynadığı önemli role dayanarak, literatürde limanların göreceli verimliliklerini araştıran ve nispeten verimsiz olanlar için yönetimsel çıkarımlar ortaya koyan birçok çalışma bulunmaktadır. Ancak çoğu durumda, limanların boyutları, yük akış potansiyelleri veya içinde bulunduklarl ortam farkl niteliklere sahip olabileceğinden verimlilik analizinden elde edilen sonuçlar kendi başına yanıltıcı olabilirler. Bu sebeple çalışmamı Türk konteyner limanlarına odaklanarak, limanları hem fiziksel özelliklerini hem de etkinlik değerlerini dikkate alarak sınıflandırmayı amaçlamaktadır. Çalışmamızda limanların etkinlik değerlerini belirlemek için veri zarflama analizi, terminallerin sınıflandırılması için ise kümeleme analizi uygulanmaktadır. Kümeleme analizinin sonuçları, limanlar için klyaslama seçeneklerinin daha iyi değerlendirilmesine imkan tanımakta ve Türk konteyner liman endüstrisinin özelliklerine genel bir bakış sağlamaktadır.
\end{abstract}

Anahtar Kelimeler: konteyner terminalleri, etkinlik, veri zarflama analizi, kümeleme analizi, klyaslama.

\section{INTRODUCTION}

"Port performance measurement" has been one of the major topics attracting the interests of maritime scholars since the late 1980s (Woo et al., 2012). This interest is mainly a result of increasing competition between ports and the significance of ports' technical efficiency in determining customers' port choice. Within this stream of literature, studies which apply data envelopment analysis (DEA) occupy the largest part. These studies basically measure relative efficiencies of selected ports/container terminals and reveal comparable results in terms of ports' success or inefficacies in managing their resources efficiently (Barros, 2003).

Moreover, DEA results are also used for revealing benchmarking alternatives for the inefficient ports (De Koster et al., 2009). These results show the closest efficient targets for the inefficient units (ports) thereby allowing these units to figure out the easiest way to become efficient (López-Espín et al., 2014). However, the benchmarking results obtained

$$
\text { ULK 2019- UDTS } 20202
$$


from classical DEA can be misleading especially when the units under investigation have disparate characteristics in terms of their physical attributes. To solve this methodological problem, researchers are now focused on alternative methods or modifications in the application that might provide better executed results which generate reasonable benchmarking alternatives. In this line, several researchers have already provided dual methodologies which are designed to alter the problem with classical DEA that generates biased benchmarking results. Wiegmans and Dekker (2016)'s study on ports in Hamburg-Le Havre range applying DEA together with single-point benchmarking and Park et al. (2019)'s study on U.S. container ports applying Kohonen's self-organizing map together with recursive DEA are two significant studies in the recent literature.

Through the combined application of DEA and cluster analysis, this study aims to propose a modification in benchmarking applications that might contribute to the "port performance measurement" literature. By using the data of Turkish container ports, this study evaluates the results obtained from the two-staged method which is expected to generate more rigorous benchmarking options when compared to the classical DEA. Other than revealing more reasonable benchmarking options, the results obtained in this study also categorizes the Turkish container ports by taking both their physical attributes and efficiencies into account.

\section{LITERATURE REVIEW}

There is a plethora of studies that are focused on efficient port management in the current port literature (Woo et al., 2012; Shi and Li, 2017). This significant interest of scholars on port efficiency studies obviously has its reasons since it is now well acknowledged that the efficient maritime supply chains can only be maintained if the ports are operated in efficient manner (Robinson, 2002) and ports need to find their own ways to increase their efficiencies considering that the competition in port industry is now as dense as it has never been (Schøyen and Odeck, 2013). Another significant reason of this scholar interest on port efficiency studies is arguably related with the ramified methodological approaches carrying the aim of increasing the sensitivity of efficiency measurements so that the results obtained from such analysis will not be misleading. In other words, it can be discussed that both the increasing importance of efficiency measurement in port management and the need for improved methodological tools to carry out efficiency analysis have been in the center of scholars' focus. Before pointing out how this current paper can potentially contribute to the existing literature on port efficiency research

ULK 2019- UDTS 20203 
in both of the above mentioned aspects, this section will briefly review the literature with a particular focus on varying methodological approaches.

Roll and Hayuth (1993)'s study on efficiency measurement using DEA on a hypothetical sample of ports was the initial study revealing how this method can be utilized in port industry setting. Since then, there has been a sharp increase in DEA based research in port literature, involving articles with very similar methodological standpoints but with different research samples. Whilst employing classical DEA method, the main attempt in increasing the robustness of the analysis was mostly focused on increasing the size of the sample as well as the number of inputs and outputs in their models (Panayides et al., 2009). Since DEA method had proved its usefulness for revealing relative efficiencies of a selected set of ports, many port clusters in different parts of the globe had been subject to these studies and the results obtained from these studies helped understanding the steps that need to be taken by the inefficient ports to improve their operations either by input/output reductions or increases. Barros and Athanassiou (2015)'s study comparing Portuguese and Greek ports, Schøyen and Odeck (2013)'s study comparing UK and Nordic ports, and Almawsheki and Shah (2015)'s study on Middle Eastern ports can present examples for these.

In tandem with the mentioned increase of efficiency assessment studies by number, many contributions have also been made in terms of methodological modifications. One of the major reasons why said modifications were critical is related with the limitations that classical DEA applications had in port industry setting in terms of their robustness when it comes to revealing the benchmarking alternatives for inefficient ports. Therefore, several important studies were carried out with the aim of proposing more robust analysis techniques which basically overcome the problem with heterogeneity (geographical and physical attributes being the major reasons) in the sample. So far, the study of Wiegmans and Dekker (2016) on ports in Hamburg-Le Havre range applying DEA together with single-point benchmarking and the study of Park et al. (2019) on U.S. container ports applying Kohonen's self-organizing map together with recursive DEA are the two significant studies which contribute to the DEA methodology in port industry setting.

The novelty of this current research lies in its methodology which combines DEA with Cluster Analysis in a sequential way. By doing so, the sensitivity of the results obtained from the analysis are improved, which enables researchers to carry out like-to-like comparisons and reveal more robust managerial implications for each of the Decision Making Units (DMUs) in the sample. As it has been voiced in several papers (e.g. 
Cullinane and Song, 2006; Tovar and Rodríguez-Déniz, 2015) that there is a need for further research which combine efficiency based benchmarking studies with port classification studies, it is believed that proposed methodology in this paper will contribute to this specific gap.

\section{METHODOLOGY}

The research model is presented in Figure 1. As it is seen in the figure, an integrated method consisting of DEA and Cluster analysis is used in our study performing said analysis techniques in a sequential order.

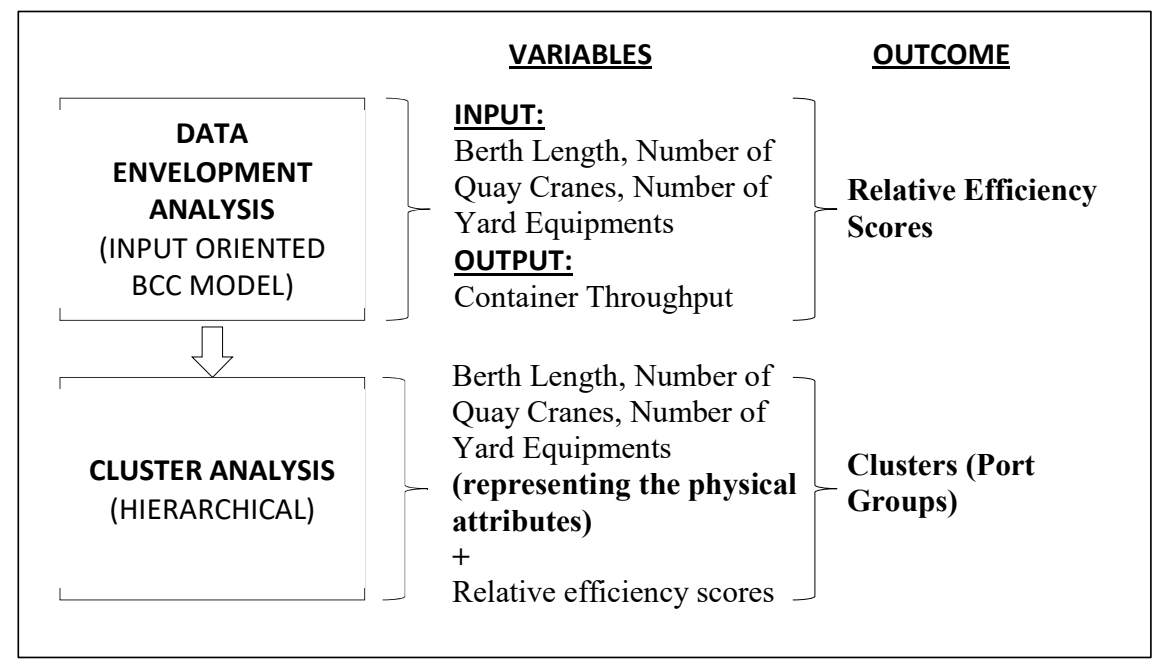

Figure 1: Research Model of the Study

This two-staged analysis process can be summarized as follows:

In the first step of the process, DEA is applied with the predetermined input and output variables and efficiency scores of the decision making units are obtained. Selection of the variables were made by examining the already existing DEA studies in the port literature and data availability. Berth length, number of quay cranes, number of yard equipment constitute the inputs while container throughput constitutes the output for the analysis. When it comes to the orientation of the analysis, input-oriented BBC model was found more appropriate since this model takes differences into account, that stem from scales of the ports. Thus, relative efficiency scores for ports are generated and more feasible values are obtained for benchmarking. 
In the following step, cluster analysis is applied using the input variables and efficiency scores that are generated in DEA. The variables used in the clustering analysis enable grouping the ports based on both their physical attributes and efficiencies. By doing so, the ports that has the highest efficiency score within each cluster represent the frontiers that can be taken as a benchmark alternative for the rest of the cluster units. Basically the second stage of the analysis aims at increasing the sensitivity of final results by grouping the decision making units based on the variables representing both the physical attributes of the ports and their relative efficiencies.

Following sections provide detailed information on DEA and cluster analysis techniques and how these techniques are utilized in this study.

\subsection{DEA}

DEA, developed by Charnes et al. (1978), is one of the most widely used linear programming based mathematical efficiency measurement techniques. This technique generates efficiency frontiers and uses decision points for the estimation of related efficiencies. The units positioned above the frontiers are considered to be efficient whereas the units located below those are considered to be inefficient. As a result of the analysis, the efficiency values range from 0 to 1 and a score of 1 indicates that the unit has reached the full efficiency level.

CCR (constant return to scale) and BCC (variable return to scale) models are the most common methods in DEA. The first data envelopment analysis model, which is mathematically modeled by Charnes et al. (1978), is CCR. This model is based on the relationship between the assumption of constant returns to scale between inputs and outputs. The BCC method developed by Banker et al. (1984) on the other hand, is a model obtained by making changes in the assumptions of the CCR model and is based on the assumption of variable returns to scale.

Data envelopment analysis is structured as input-oriented or outputoriented based on the purpose of the study. If the objective is to identify units that use more resources, the input-oriented model should be focused. However, if the objective is to increase output, the appropriate model is the output-oriented model (Cook et al., 2014). Also, according to Dyson et al. (2001) the number of DMUs must be at least 2 times the number of inputs and outputs used in the model to achieve a reasonable level of discrimination. 
In this study, BCC model was preferred since this model carries out efficiency assessment taking the varying scales of the DMUs into account. Stated differently, BCC model generates more suitable results that can be utilized as inputs of cluster analysis in comparison to CCR model. For the benchmarking analysis to become more robust, this selection of the model is considered to be one of the significant attempts of this research's methodology.

\subsection{Cluster Analysis}

Cluster analysis is used extensively in the fields of science, such as social sciences, education, medicine, biology, psychology, sociology, archeology and marketing. It is a multivariate analysis technique that divides individuals or subjects into different clusters and groups the data according to their technical characteristics. Similar objects are placed in the same cluster, thus maximizing homogeneity within each cluster and heterogeneity between clusters (Karagöz, 2016:899). As the number of variables increases in clustering analysis, the number of data will have to increase. It would be better for the reliability of the analysis if the number of data is approximately 3-4 times the number of variables.

There are many types of clustering techniques. Hierarchical cluster analysis is one of the most widely used one and is found to be appropriate for the present study. In this technique, the number of clusters is not known in advance and is left to the conclusion of the analysis (Grebitus, 2008). Also, hierarchical clustering analysis are appropriate especially for small samples (Bacher, 1994).

\subsection{Data}

In this article, DMUs consist of private Turkish ports that carry out container operations. Sample of the study includes 17 ports that handled above 50000 TEUs in the year of 2016. As a result of the selection criteria, Limaş, Port of Trabzon, Çelebi Bandırma, Ulusoy Çeşme, Safiport Derince and Akçansa are excluded from the analysis as their container throughputs are under 50000 TEU.

The DEA model is designed with 3 inputs and 1 output. The inputs of the model are berth length allocated to container handling (x1), number of quay cranes (x2) and number of yard equipment used for storage activities (x3). The model output is container throughput (y1) of selected container terminals in the year of 2016. The DEA model used in this study 
involving 3 inputs and 1 output from 17 DMUs meets the requirement of Cooper et al (2001), and thus performs high level of validity.

The data of the input variables used in the study are compiled primarily from the websites of the ports, and the data not included in these websites are obtained via telephone and email. The output variable of the study for 2016 container throughput values are obtained from TURKLIM 2017 Port Sector Report (TURKLIM, 2017). Descriptive statistics of the inputs and output variables can be seen at Table 1.

Table 1: Descriptive Statistics for the 17 Container Ports in Turkey

\begin{tabular}{|l|c|c|c|c|}
\hline & Mean & Max. & Min. & Std. Dev. \\
\hline Inputs & & & & \\
\hline Berth Length & 1036 & 2385 & 440 & 529 \\
\hline Number of Quay Cranes & 8 & 18 & 3 & 4 \\
\hline Number of Yard Equipment & 25 & 60 & 6 & 17 \\
\hline Output & & & & \\
\hline Container Throughput & 471695,2 & 1846995 & 51553 & 493502,2 \\
\hline
\end{tabular}

Majority of the terminals in the sample are multiple purpose terminals serving for not only the containerized cargo but also for other cargo types. Therefore, it was decided not to involve storage area as an input variable since it would lead to miscalculations. In addition, the number of berths was also excluded as an input variable due to the fact that several of the ports use their berths both for handling of containerized cargo and other cargo types.

The relevance of the variables used in the model can be determined by evaluating the correlation coefficients in between. As it is seen in Table 2 , all the correlation coefficients are positive and at significant levels. Therefore, the correlation matrix justifies the inclusion of these variables to the model as it shows the isotonic relationship.

Table 2: Correlation between Variables

\begin{tabular}{|l|c|c|c|c|}
\hline & $\begin{array}{c}\text { Berth } \\
\text { Length }\end{array}$ & $\begin{array}{c}\text { Number } \\
\text { of Quay } \\
\text { Crane }\end{array}$ & $\begin{array}{c}\text { Number of } \\
\text { Yard } \\
\text { Equipment }\end{array}$ & $\begin{array}{c}\text { Container } \\
\text { Throughp } \\
\text { ut }\end{array}$ \\
\hline Berth Length & 1.0000 & & & \\
\hline $\begin{array}{l}\text { Number of Quay } \\
\text { Cranes }\end{array}$ & $\begin{array}{c}0.806749 \\
(0.0001)\end{array}$ & $\begin{array}{c}1.0000 \\
----\end{array}$ & & \\
\hline
\end{tabular}

ULK 2019- UDTS 20208 


\begin{tabular}{|l|c|c|c|c|}
\hline Number of Yard & $\begin{array}{c}0.765178 \\
\text { Equipment }\end{array}$ & $\begin{array}{c}0.942295 \\
(0.0003)\end{array}$ & $\begin{array}{c}1.0000 \\
----\end{array}$ & \\
\hline Container & 0.719232 & $0.85000)$ & 0.924236 & 1.0000 \\
Throughput & $(0.0017)$ & $(0.0000)$ & $(0.0000)$ & ----- \\
\hline
\end{tabular}

Note: The values given in parentheses below the correlation coefficients indicate the significance of the correlations.

\section{RESULTS}

The results of the DEA on the sample are presented in Table 3. According to the results of input-oriented BCC (variable return to scale), 11 DMUs (ports) with the scores that are less than 1 are found to be relatively inefficient whereas a large number of DMUs consisting of 6 ports are found to be efficient. Table 3 presents the scores as well as the ranks of each port under investigation.

Table 3: Efficiency Score, Ranking and Reference Set of Ports

\begin{tabular}{|l|c|c|}
\hline \multicolumn{1}{|c|}{ DMU Name } & Score & Rank \\
\hline Marport & 1,00 & 1 \\
\hline MIP (Mersin) & 0,80 & 10 \\
\hline Asya Port & 0,60 & 16 \\
\hline Evyapport & 0,96 & 7 \\
\hline Kumport & 0,61 & 15 \\
\hline Yilport & 0,77 & 11 \\
\hline Ege Gübre (TCEEGE) & 1,00 & 1 \\
\hline Gemport & 0,70 & 12 \\
\hline Mardaş & 0,57 & 17 \\
\hline Nemport & 0,88 & 9 \\
\hline Borusan & 1,00 & 1 \\
\hline Limak İskenderun & 0,65 & 13 \\
\hline Port Akdeniz & 1,00 & 1 \\
\hline Assan Port & 1,00 & 1 \\
\hline Rodaport & 0,92 & 8 \\
\hline Samsunport & 1,00 & 1 \\
\hline DP World Yarımca & 0,61 & 14 \\
\hline
\end{tabular}

Following the implementation of DEA, cluster analysis is applied in order to reveal appropriate benchmarking alternatives. In the cluster analysis, the variables included inputs (berth length, number of quay cranes, number of yard equipment) previously used in DEA as well as the efficiency scores obtained from DEA. The values are standardized between 0 and 1. Hierarchical cluster analysis is applied with Ward Linkage method. Its results provide a dendogram which is a tool for identifying the 
clusters (Afifi et al., 2011:415). This dendogram can be seen in Figure 2. As a result of the evaluations, it is determined that the cut off value should be applied to form 5 clusters between 0 and 5 values.

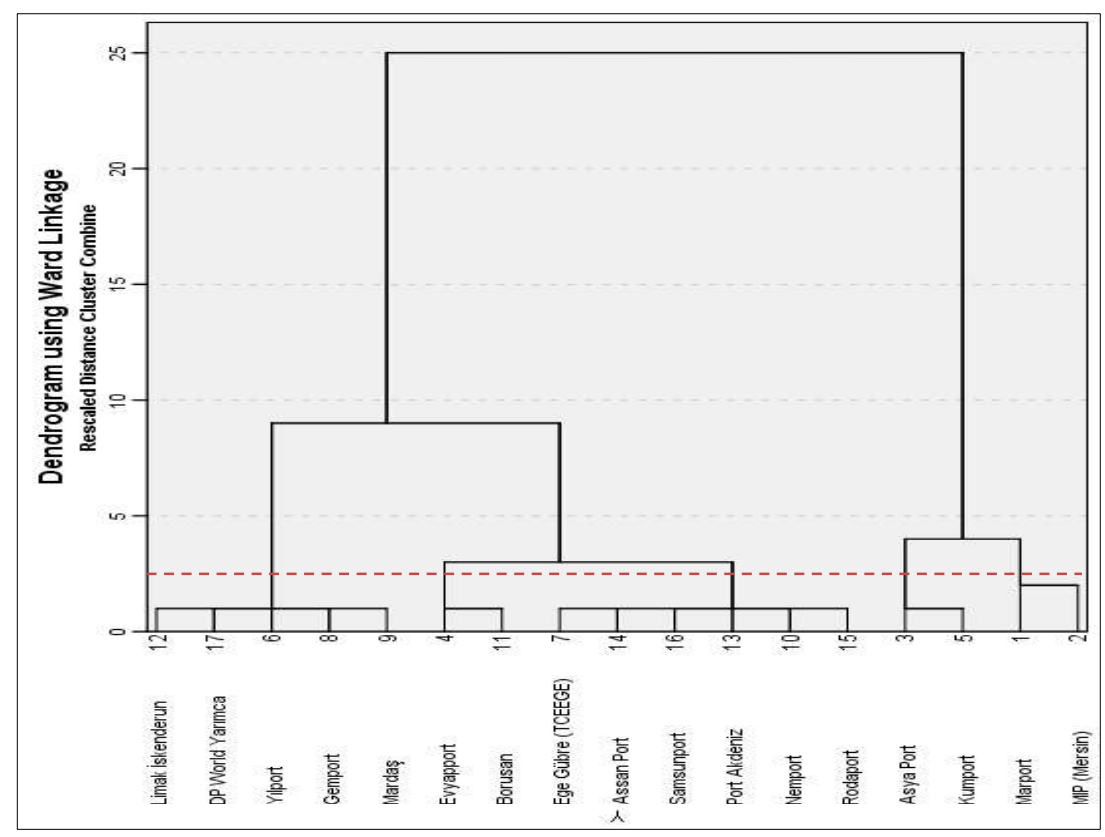

Figure 2: Dendogram Obtained from Cluster Analysis

The clusters formed after the detection of the cut off line are presented in Table 4 . Accordingly, the first 3 clusters contain 2 ports, while the others contain 5 and 6 ports.

Table 4: Clusters Formed Using Hierarchical Method

\begin{tabular}{|c|l|}
\hline Cluster & Port Name \\
\hline \multirow{2}{*}{1} & Marport \\
\cline { 2 - 2 } & MIP (Mersin) \\
\hline 2 & Asya Port \\
\cline { 2 - 2 } & Kumport \\
\hline \multirow{2}{*}{3} & Evyapport \\
\cline { 2 - 2 } & Borusan \\
\hline \multirow{4}{*}{4} & Y1lport \\
\cline { 2 - 2 } & Gemport \\
\cline { 2 - 2 } & Mardaş \\
\cline { 2 - 2 } & Limak İskenderun \\
\cline { 2 - 2 } & DP World Yarımca \\
\hline \multirow{2}{*}{5} & Ege Gübre (TCEEGE) \\
\cline { 2 - 2 } & Nemport \\
\hline
\end{tabular}

ULK 2019- UDTS 202010 


\begin{tabular}{|l|l|}
\hline \multirow{4}{*}{} & Port Akdeniz \\
\cline { 2 - 2 } & Assan Port \\
\cline { 2 - 2 } & Rodaport \\
\cline { 2 - 2 } & Samsunport \\
\hline
\end{tabular}

In the following step, the descriptive statistics of the identified clusters are examined which help determining the characteristics of the ports in each of the clusters. These statistics are presented in Table 5. Based on these statistics, it can be concluded that efficient ports are divided into 3 different groups. Cluster 1 includes ports with high inputs and high efficiency scores; Cluster 5 includes ports with high efficiency scores and low inputs; and the Cluster 3 is the group of efficient ports whose inputs are at moderate levels. When it comes to the inefficient ports: Cluster 2 contains the inefficient ports with high inputs whereas Cluster 4 consists of the inefficient ports with low inputs.

Table 5: Mean Values of Variables by Clusters

\begin{tabular}{|l|c|c|c|c|c|}
\hline & \multicolumn{5}{|c|}{ Clusters } \\
\hline Variables & $\mathbf{1}$ & $\mathbf{2}$ & $\mathbf{3}$ & $\mathbf{4}$ & $\mathbf{5}$ \\
\hline Berth Length & 1995 & 1677 & 632 & 876 & 770 \\
\hline Number of Quay Cranes & 17 & 13 & 9 & 8 & 4 \\
\hline Number of Yard Equipment & 60 & 40 & 26 & 24 & 9 \\
\hline Efficiency Score & 0,90 & 0,60 & 0,98 & 0,66 & 0,97 \\
\hline
\end{tabular}

\section{CONCLUSION}

The method applied in this study distinguishes itself from the classical efficiency measurement methodology since it is followed up by cluster analysis that allow better assessment of benchmarking alternatives. The variables employed in the cluster analysis enable grouping the ports based on both their physical attributes and efficiencies. By doing so, the ports that has the highest efficiency score within each cluster represent the frontiers that can be taken as a benchmark alternative for the rest of the cluster members.

When compared to the benchmarking evaluations that is solely based on classical DEA, this proposed method is considered to provide more accurate results since the clustering ports based on physical attributes help filtering reasonable benchmarks. Other than revealing the benchmarking alternatives, this method also enables understanding the characteristics of Turkish container ports in terms of their physical attributes and efficiencies. The findings of this study show that Turkish container ports can be classified into 5 groups. According to this classification, not all the efficient ports have similar characteristics. In

$$
\text { ULK 2019- UDTS } 202011
$$


other words, while several efficient ports have low input levels others have high input levels. This difference basically creates an advantage for the inefficient ports for finding out more suitable benchmarking alternatives that are closer to their physical attributes.

Considering that this study is mainly an attempt on proposing a methodological contribution, further applications of the proposed method can be critical to see how it works with different sample sizes and/or variables on physical attributes that have not been employed in this study. One of the significant limitation of this study is related with the data availability on pure container storage area of selected container ports. Considering that this area is one of the most critical aspects of container ports' physical attributes, its absence can be seen as a factor that might cause misrepresentations. Therefore, inclusion of this input can restructure the existing clusters in a more robust direction. However, this specific data is not available for majority of Turkish container ports which handle various cargo types other than containers. Still, further research can overcome this data related limitation by finding out alternative methods for data collection such as field investigations.

\section{REFERENCES}

Afifi, A., May, S. and Clark, V. A. (2011). Practical Multivariate Analysis. US: CRC Press.

Almawsheki, E. S. and Shah, M. Z. (2015). Technical efficiency analysis of container terminals in the middle eastern region. The Asian Journal of Shipping and Logistics, 31 (4), 477-486.

Bacher, J. (1994). Clusteranalyse. Anwendungsorientierte Einführung. Germany: Oldenbourg Verlag.

Banker, R. D., Charnes, A. \& Cooper, W. W. (1984). Some models for estimating technical and scale inefficiencies in data envelopment analysis. Management Science, 30 (9), 1078-1092.

Barros, C. P. (2003). The measurement of efficiency of Portuguese sea port authorities with DEA. International Journal of Transport Economics, 30 (3), 335-354.

Barros, C. P. and Athanassiou, M. (2015). Efficiency in European seaports with DEA: evidence from Greece and Portugal, in H.E. Haralambides (Ed.), Port Management, pp. 293-313. London: Palgrave Macmillan. 
Charnes, A., Cooper, W.W. and Rhodes, E. (1978). Measuring the Efficiency of Decision Making Units. European Journal of Operational Research, 2 (6), 429-444.

Cook, W. D., Tone, K. and Zhu, J. (2014). Data envelopment analysis: Prior to choosing a model. Omega, 44, 1-4.

Cullinane, K. and Song, D. W. (2006). Estimating the relative efficiency of European container ports: a stochastic frontier analysis. Research in Transportation Economics, 16, 85-115.

De Koster, M. B. M., Balk, B. M. and Van Nus, W. T. I. (2009). On using DEA for benchmarking container terminals. International Journal of Operations \& Production Management, 29 (11), 1140-1155.

Dyson, R. G., Allen, R., Camanho, A. S., Podinovski, V. V., Sarrico, C. S., and Shale, E. A. (2001). Pitfalls and protocols in DEA. European Journal of operational research, 132 (2), 245-259.

Grebitus, C. (2008). Food Quality from The Consumer's Perspective: An Empirical Analysis of Perceived Pork Quality. Germany: Cuvillier Verlag.

Karagöz, Y. (2016). SPSS ve AMOS 23 Uygulamalı Istatiksel Analizler. Ankara: Nobel Akademik.

López-Espín, J. J., Aparicio, J., Giménez, D. and Pastor, J. T. (2014). Benchmarking and data envelopment analysis. An approach based on metaheuristics. Procedia Computer Science, 29, 390-399.

Panayides, P. M., Maxoulis, C. N., Wang, T. F. and Ng, K. Y. A. (2009). A critical analysis of DEA applications to seaport economic efficiency measurement. Transport Reviews, 29 (2), 183-206.

Park, Y. S., Mohamed Abdul Ghani, N. M. A., Gebremikael, F. and Egilmez, G. (2019). Benchmarking environmental efficiency of ports using data mining and RDEA: the case of a US container ports. International Journal of Logistics Research and Applications, 22 (2), 172-187.

Robinson, R. (2002). Ports as elements in value-driven chain systems: the new paradigm. Maritime Policy \& Management, 29 (3), 241-255.

Roll, Y. and Hayuth, Y. (1993). Port performance comparison applying data envelopment analysis (DEA). Maritime Policy \& Management, 20 (2), 153-161.

Schøyen, H. and Odeck, J. (2013). The technical efficiency of Norwegian container ports: A comparison to some Nordic and UK container ports

ULK 2019- UDTS 202013 
using Data Envelopment Analysis (DEA). Maritime Economics \& Logistics, 15 (2), 197-221.

Shi, W. and Li, K. X. (2017). Themes and tools of maritime transport research during 2000-2014. Maritime Policy \& Management, 44 (2), 151169.

Tovar, B. and Rodríguez-Déniz, H. (2015). Classifying ports for efficiency benchmarking: A review and a frontier-based clustering approach. Transport Reviews, 35 (3), 378-400.

TURKLIM (2017). Port sector report. Türkiye Liman İşletmecileri Derneği,.İstanbul.

Wiegmans, B. and Dekker, S. (2016). Benchmarking deep-sea port performance in the Hamburg-Le Havre range. Benchmarking: An International Journal, 23 (1), 96-112.

Woo, S. H., Pettit, S., Beresford, A. and Kwak, D. W. (2012). Seaport research: A decadal analysis of trends and themes since the 1980s. Transport Reviews, 32 (3), 351-377. 